http://dx.doi.org/10.11646/phytotaxa.159.1.4

\title{
Elettariopsis biphylla, a new species of Zingiberaceae from Thailand
}

\author{
SURAPON SAENSOUK ${ }^{1} \&$ PIYAPORN SAENSOUK ${ }^{2,3}$ \\ ${ }^{\prime}$ Biodiversity program, Walai Rukhavej Botanical Research institute, Mahasarakham University, Tambol Khamriang, \\ Kantarawichai District, Mahasarakham province, 44150, Thailand \\ ${ }^{2}$ Departmet of Biology, Faculty of Science, Mahasarakham University, Tambol Khamriang, Kantarawichai District, Mahasarakham \\ province, 44150, Thailand \\ ${ }^{3}$ Corresponding author, e-mail: pcornukaempferia@yahoo.com
}

A new species of Elettariopsis from Phu Wua Wildlife Sanctuary, Bung Khla District, Bueng Kan Provice, Thailand is described as a new species. The new species is similar to E. monophylla (Gagnep.) Loesener (1930: 603), but differs in having two leaves and dark red veins in parts of the labellum, in the length of the petioles, the tall pseudostem and the apex of the anther-crest. Differences are pointed out in Table 1. The species is locally rare occurring in lowland Phuwou forest. It is described and illustrated below.

\section{Elettariopsis biphylla S.Saensouk \& P.Saensouk, sp. nov. (Figs. 1-6)}

The species has two distinctive leaves and dark red veins in parts of the labellum. The morphological characters of E. biphylla are similar to those of E. monophylla but it differs in its two leaves, dark red veins in parts of the labellum and length of petioles, the pseudostem and the apex of the anther crest.

Type:-THAILAND. Bueng Kan Province: Bung Khla District, Phu Wua Wildlife Sanctuary, elevation 140 m.,May 2013, Saensouk 400 (holotype BK!, isotypes BKF!, KKU!, QSBG!).

Perennial herbs, 30-35 cm; rhizomes creeping, slender, bearing pseudostems at intervals. Bladeless leaf 1, normal leaves 2; ligules 1-2 mm, apex bilobed, glabescent; petioles 9-12 cm, glabrous, green, channeled; leaf blades lanceolate-oblong or elliptic, 20-30 $\times 5-10 \mathrm{~cm}$, apex acuminate or mucronate, base attenuate, margin entire to slightly undulate, both sides glabrous, upper surface dark green, lower surface lighter green. Inflorescences arising from the rhizome between bases of pseudostems, with flowers in an erect dense head. Peduncles $0.6-1.2 \mathrm{~cm}$. Bracts 6-8, lanceolate, light pinkh, c. $2.0 \times 0.7 \mathrm{~cm}$. Bracteoles lanceolate, $1.5 \times 3.5 \mathrm{~mm}$. Calyx tubular, $2.7-3.0 \mathrm{~cm}$, usually longer than the corolla tube, pinkish to reddish white with yellowish apex, lobes 3 , yellowish; dorsal lobe pinkish to reddish, oblong, c. $1.8 \times 1.0 \mathrm{~cm}$, hooded; lateral lobes pinkish to reddish, oblong, c. $1.8 \times 7.0 \mathrm{~mm}$, slightly hooded. Lateral staminodes absent. Labellum suborbicular, c $2.5 \times 2.0 \mathrm{~cm}$, white with a dark red band at the base and a yellow band in the middle, hairy towards the throat; base clawed, 5-8 mm; veins dark red; distal part 3-lobed, the median lobe crenate, sometimes slightly emarginate. Filament short, c. $5 \times 3 \mathrm{~mm}$, yellowish. Anther c. $4 \times 3 \mathrm{~mm}$; anther-crest, whitish, c. $3 \times 2 \mathrm{~mm}$, apex obtuse. Ovary 2-5 $\times 2-4 \mathrm{~mm}$, pubescent, stylodes 2 , slender, $5-$ $6 \times$ ca. $1 \mathrm{~mm}$, not surrounding the style; stigma triangular with ciliate apex, inconspicuous. Flowering from March to May. Fruits not seen.

Distribution:-Endemic to Thailand, only known from Bueng Kan Province Bung Khla District, (Phu Wua Wildlife Sanctuary)

Habitat:- This species grows in the shade of mixed deciduous forest at an elevation of ca. $140 \mathrm{~m}$.

Vernacular names:-Khing-Nok-Kho.

Ethnobotany:-Even though this species has only recently been discovered, its fresh young leaves are eaten as a vegetable in Northeastern Thai cuisine. 


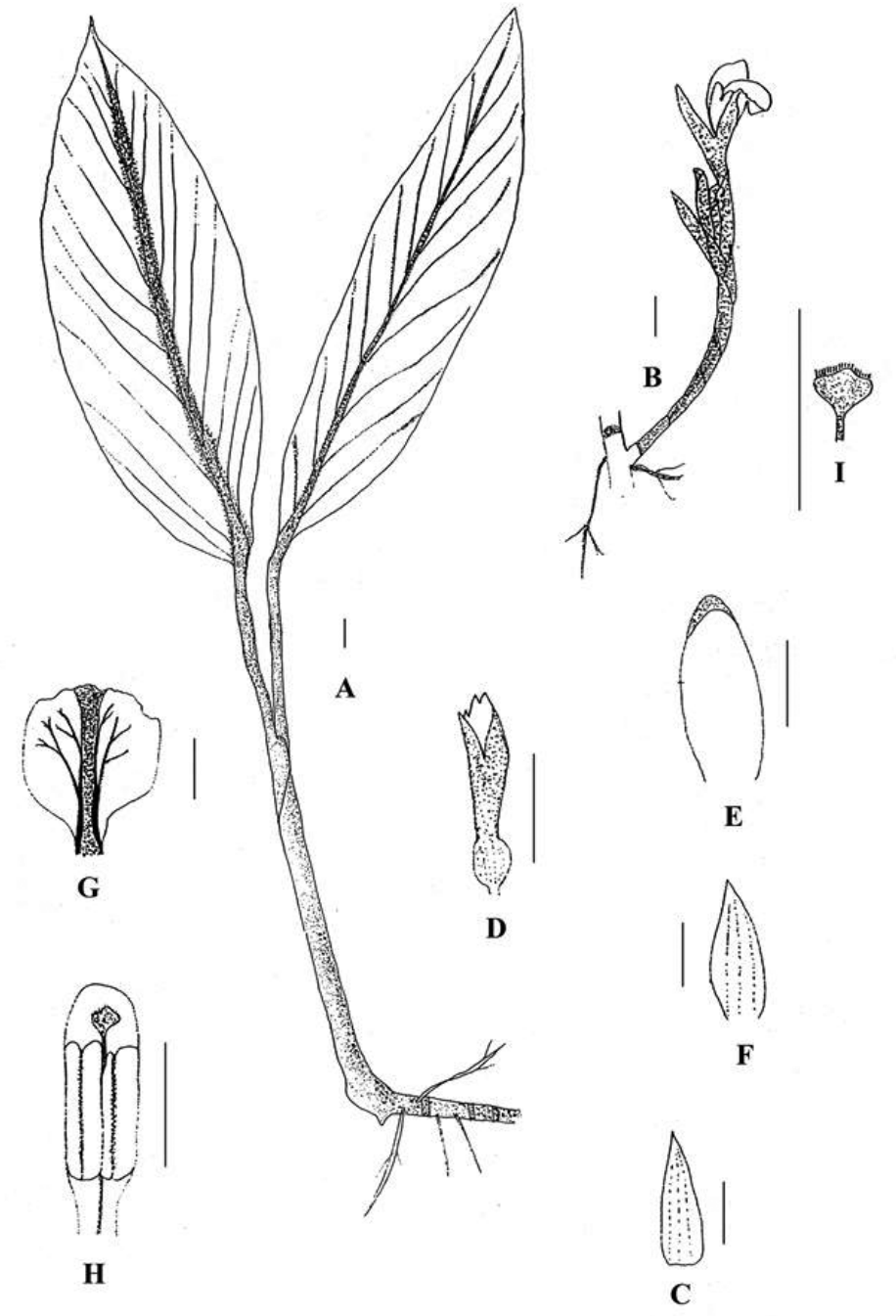

FIGURE 6: Elettariopsis biphylla. A: plant habit, showing leafy stem. B: inflorescence.C: bract. D: calyx tube and ovary. E: dorsal corolla lobe. F: lateral corolla lobe. G: labellum. H: anther, anther crest and stigma. I: stigma (scale bars $=1 \mathrm{~cm})$

\section{References}

Baker, J.G. (1892) Scitamineae. In: Hooker, J.D. Flora of British India 4: 198-265.

Holttum, R.E. (1950) The Zingiberaceae of the Malay Peninsular. The Garden Bulletin, Singapore 8: 249.

Kam, Y.K. (1982) The genus Elettariopsis (Zingiberaceae) in Malaya. Notes from the Royal Botanic Garden Edinburgh 40: $139-152$.

Larsen, K. \& Larsen, S.S. (2006) Gingers of Thailand. Queen Sirikit Botanic Garden, Chiang Mai.

Larsen, K. (1996) A preliminary checklist of the Zingiberaceae of Thailand. Thai Forest Bulletin (Botany) 24: 35-49.

Lim, C.K. (2003) Taxonomic notes on Elettariopsis Baker, and new taxa from Peninsular Malaysia. Folia Malaysiana 4: 205206.

Loesener, L.E.T. (1930) Zingiberaceae. In: Engler, A. \& Prantl, K. (eds.) Die natürlichen Pflanzenfamilien, ed. 2, 15a. Duncker \& Humblot, Berlin.

Saensouk, S. \& Chantaranothai, P. (2003) The Family Zingiberaceae in Phu Phan National Park. In: Chantaranothai, P., Larsen, K., Sirirugsa, P., \& Simpson, D. (eds.) Proceedings of the 3rd Symposium on the family Zingiberaceae 7-12 July 2002. Khon Kaen University, Khon Kaen, pp. 16-25.

Picheansoonthorn, C. \& Yupparach, P. (2010) Further study on the Elettariopsis Baker (Zingiberaceae) in Thailand - a new species and a new necord. Taiwania 55: 335-341. 